\title{
115. Ein verbessertes Verfahren der Magenresektion
}

\author{
Shoen Cho, Seimai Cho und Seiko Zyo \\ Cho-Clinic, Tsuruaka, Japan, I. Path. Institut, Yokohama, Japan
}

\section{New and Improved Method of Gastric Surgery: Shiota-Cho's Method of Gastric Resection}

Summary. During 28 years, 1618 cases were operated on with all different kinds of anastomotic methods between the stomach remnant and the jejunum. The procedure yielding the best result was antiperistaltic anastomosis of the jejunal segment to the antecolonic stomach remnant followed by the construction of two Braun's anastomoses between the afferent and efferent loops, the one $8 \mathrm{~cm}$ from the stomach remnant, the another $8 \mathrm{~cm}$ below. This method had several advantages: postoperative dumping syndrome was not seen in any of these cases; the afferent-loop syndrome was also avoided; the procedure is possible even with total gastrectomy; and both solid foods and liquid passed more easily through the anastomotic sites.

Key words: Gastrectomy, total - Anastomosis, antiperistaltic, antecolonic, Braun's.

Zusammenfassung. Auf Grund von Nachuntersuchungen bei Magenresektionen in 1618 Fällen halten wir folgendes Verfahren für das beste. Restmagen wird mit Jejunum antiperistaltisch vor dem Quercolon anastomosiert und danach zwei große Braunsche Anastomosen zwischen dem afferenten und efferenten Jejunum durchgeführt, die erste $8 \mathrm{~cm}$ unterhalb des Restmagens, die zweite $8 \mathrm{~cm}$ darunter. Die Vorteile sind, da $B$ Dumpingsyndrom und Efferentssegmentleiden vermieden werden und das Verfahren auch bei der totalen Magenresektion anwendbar ist. Feste Nahrung und Flüssigkeit, hinreichend mit Verdauungssaft gemischt, passieren besser die Anastomosenstelle.

Schliisselwörter: Große Magenresektion - Zwei Braunsche Anastomosen, antiperistaltisch antecolonisch.

\section{Der peritoneovenöse Shunt zur Behandlung des therapieresistenten Ascites}

\author{
G. Jacobs und K. Kremer \\ Chirurgische Klinik A, Universität Düsseldorf
}

\section{Treatment of Ascites with a Peritoneovenous Shunt}

Summary. The backflow of sequestrated ascitic fluid into the circulation can be achieved with a valve developed by $\mathrm{H}$. LeVeen. When in position between the peritoneal cavity and the vena cava superior, the valve leads the ascitic fluid into the venous system because of the difference in pressure at this point. The shunt is indicated in all patients with ascites that cannot be succesfully treated with drugs or another operation. Hemodilution, large amounts of urine, weight loss, and decreasing circumference of the abdomen are signs of good functioning of the shunt. In the presence of high venous pressure the shunt is not effective.

Key words: Ascites: Treatment - Shunt, peritoneovenous - Valve, LeVeen. 